\title{
Indonesia Stock Exchange Securities Buy/ Sell Signal Detection using Bollinger Bands and Williams Percent Range
}

\author{
Ike Pertiwi Windasari, Agung Budi Prasetijo, Reza Pahlevi Pangabean \\ Department of Computer Engineering \\ Faculty of Engineering - Diponegoro University \\ Semarang, Indonesia \\ \{ike, agung, rfpanggabean \}@ce.undip.ac.id
}

\begin{abstract}
For stock investor, it is important to be able to predict future stock prices to find out the possible gains or losses obtained. In the world of stock investment, stock price prediction is applied with two approaches, namely analysis and fundamental analysis. This detection application system was developed using a technical analysis approach.

Technical analysis is a method used to observe price fluctuations in a certain time span by utilizing historical data using indicators. Bollinger Bands and Williams Percent Range are indicator used in this study to provide information on the movement of a stock by observing a particular pattern of patterns used as a basis for buying or selling. The data used in this study is six companies whose shares are listed as LQ45 in Indonesia Stock Exchanges.
\end{abstract}

The results show that the combination of indicators over a period of one year can provide the greatest benefit, namely by $\mathbf{8 0 . 2 0 \%}$ in Aneka Tambang shares and the average performance of a total of 6 shares is $10.72 \%$ using strategy 1, an Exit Bollinger with confirmation by Williams Percent Range.

Keywords-Bollinger Bands, William Percent Range, Indonesia Stock Exchange, LQ45

\section{INTRODUCTION}

In implementing the national economic development of a country, financing is needed from both the government and the community [1]. Thus, the capital market as an alternative financing of development, must be able to facilitate the development of market economy [2].

In the capital market, investors can invest through ownership of various securities (equity). In investment, it is widely known that the higher the expected profit level, the higher the level of risk that is likely to be faced and vice versa.

Many traders experience difficulties or confusion when taking a buy or sell position, in fact many signals of stock movements as a reference can be obtained for free via the Internet. However, if you are observant and want to learn stock investment, you must learn technical analysis and fundamental analysis. Because, basically traders make trading decisions using both analyzes [3]. Technical Analysis is quite often used by potential investors and usually the data used in this analysis is in the form of graphics, or computer programs. Graphics or computer programs can be used to predict market trends, securities, or commodity futures that should be selected in investing [4].

Technical analysis as it is very suitable for predicting a stock price movement in the short term, medium term, or long term [5]. Indicators are tools used for graphic analysis.
Indicators combining is often used by investors to avoid false signals. Indicators combining is also used to complement between indicators. Indicators that are often used for combining are Oscillators and Volatility. Oscillator is an indicator used to determine prices or market conditions classified as oversold or overbought. This momentum can be used to determine whether prices will change or continue to follow trends. Examples of Oscillators are Williams Percent Range, Stochastic, Relative Strength Index (RSI), and Commodity Channel Index (CCI). While Volatility is often used to measure a relatively dynamic level of price movement. In terms of trading, it is used as a marker of rising or falling prices, Examples of Volatility are Bollinger Bands (BB), Moving Average (MA), Average True Range, etc. Some research are using Bollinger Bands and show good result while combined with other method [6][7].

Bollinger bands is used to identify whether the stock price is relatively high or low. Stock prices are considered high when they touch the upper bands and are low when they touch the lower bands [6]. Williams Percent Range is designed to show the difference between a high period and today's closing price with a certain trading range. The indicator shows the relative situation of the closing price in the observation period [3]. With the Bollinger bands indicator as a trend level gauge on the market (Volatility), and Williams Percent Range as a determinant of momentum in determining the entry point (Oscillator), it is expected to provide a buy or sell signal appropriately.

The remainder of this paper is as follows. Stock technical analysis indicators are explained in Section 2. Section 3 provide the research method. Result and discussion from this research are explained in Section 4 and Section 5 will provide conclusion of this paper.

\section{STOCK TECHNICAL ANALYSIS INDICATORS}

In this section, we will revisit two stock technical analysis indicators that we use in this study.

\section{A. Bollinger Bands}

Bollinger Bands is an analytical method developed by John Bollinger which is used to compare volatility and relative prices in one analysis period. Bollinger Bands consist of three designed to create a zone that can cover the majority of price movements [3]. This three zone is displayed as three bands that called middle band, upper band, and lower band. Equation 1,2 , and 3 show the formula to create upper band, middle band, and lower band as shown in Figure 1. 


$$
\begin{aligned}
& U B_{d}=S M A_{d}+\left(2 . S t d D e v_{d}\right) \\
& M B_{d}=S M A_{d} \\
& L B_{d}=S M A_{d}-\left(2 . S t d D e v_{d}\right)
\end{aligned}
$$

Where $S M A_{d}$ is an average of closing price of stocks for $d$ days and $S t d D e v_{d}$ (Standard Deviation of Price) is a standard deviation of closing price of stocks for $d$ days. $S t d D e v_{d}$ formula can be written as follows:

$$
S t d D e v_{d}=\sqrt{\frac{\sum_{i=1}^{N}\left(C_{d}-\overline{C_{N}}\right)^{2}}{\sum_{i=1}^{N} C_{d}}}
$$

Where $C_{d}$ is the closing price of stocks, $C_{N}$ is $S M A_{d}$, and $N$ is a total days calculated.

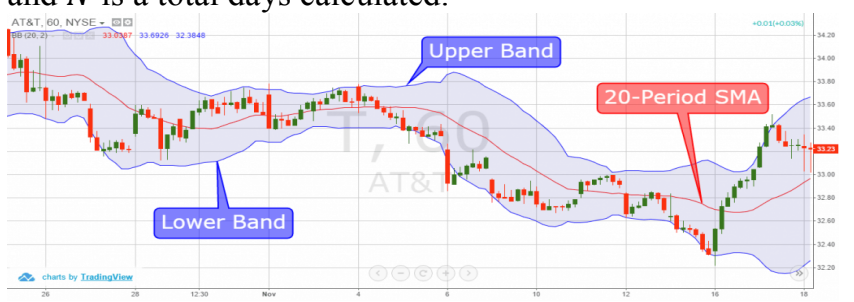

Fig. 1. Sample chart of Bollinger Bands

\section{B. Williams Percent Range}

Larry Williams uses the same concept as the Stochastics indicator that calculates the relationship between price ranges for several days. Today's closing price will be deducted from the highest price in the price range for several days and the difference will be divided by the total range in the same period.

The interpretation of the Williams Percent Range is the same as the Stochastics Oscillators, except that the Williams Percent Range is described as upside down while the Oscillator has internal smoothing.

An interesting phenomenon from the Williams Percent Range indicator is its ability to anticipate a reversal of stock prices. This indicator almost always forms a peak and turns around a few days before the stock price reaches its peak and turns around [8].

Williams Percent Range is the concept of current price measurement, how much the current share price is changing. The upper limit of $\% \mathrm{R}$ is used by -80 and the lower limit is 20. As a signal to enter the market is if the stock price approaches -20 and crawls up the market exit signal is if the stock price approaches -80 and moves down [9] as shown in Figure 2.

The Williams Percent Range indicator can be calculated using the formula shown in equation 5 .

$$
\% R=\frac{\text { Highest High }- \text { Close }}{\text { Highest High }- \text { Lowest Low }} \times-100
$$

Where Close is the closing price of stocks, Highest High is the highest stock price over a period of time, and Lowest Low is the lowest stock price over a period of time.

\section{RESEARCH METHOD}

This study aims to create an application that uses a combination of Bollinger Bands and William Percent Range. Combinations are made into five strategies. Method used our system is Data Collection, Strategy Formulation and followed by Application Design.

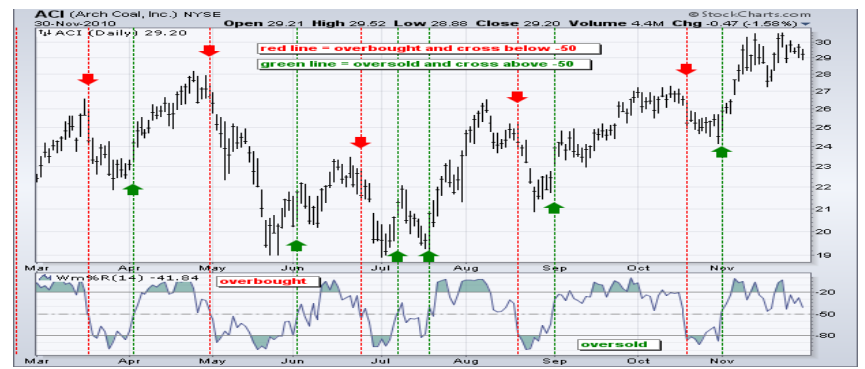

Fig. 2. Sample chart of Williams Percent Range

\section{A. Data Collection}

The research objects used were six LQ45 shares listed on the Indonesia Stock Exchange namely Perusahaan Gas Negara, Waskita Karya, Aneka Tambang, Adaro Energy, Telekomunikasi Indonesia and Indika Energy. We used data from 28 August 2017 to 28 August 2018. Stock data is taken from Indonesia Stock Exchange (IDX) using Alpha Vantage API.

\section{B. Strategy Formulation}

There will be five strategies provided for this application based on combination of Bollinger Bands and William Percent Range. The strategy is as follows:

1) Bollinger Bands Strategy. This strategy uses Bollinger Bands indicator to determine the signal that is issued. Signals to buy or sell will come out if the price closes (close) by exceeding the upper bands limit or less than the lower bands line. This strategy is enough to only use 2 lines in bollinger bands as a reference in determining buy and sell signals. Figure 3 shows graphic signal of Bollinger Bands Strategy.

Close $\leqslant$ LowerBand, then Buy signal.

Close $\geqslant$ UpperBand, then Sell signal.

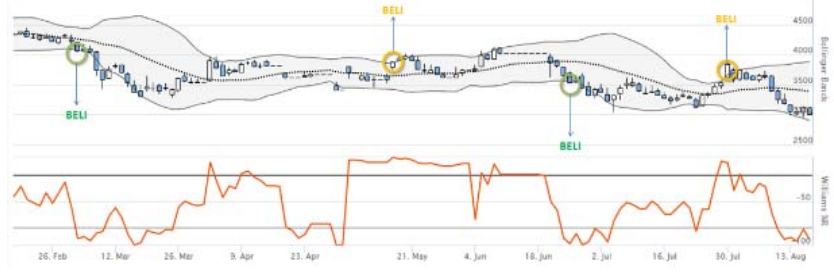

Fig. 3. Graphic signal of Bollinger Bands Strategy

2) Williams Percent Range Strategy. This strategy utilizes the Williams percent range indicator to determine the signal issued. Signals to buy or sell will come out if the price closes (close) in an overbought or oversold area. In this strategy set the overbought area above the -20 level and the oversold area below the -80 level. Figure 4 shows graphic signal of Williams Percent Range Strategy.

$$
\begin{aligned}
& \% R \geqslant-20, \text { then Sell signal. } \\
& \% R \leqslant-80 \text {, then Buy signal. }
\end{aligned}
$$

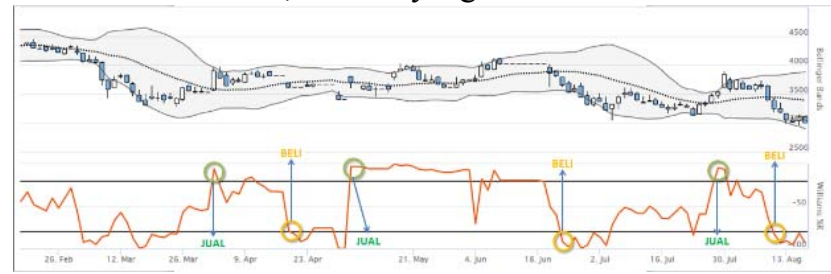

Fig. 4. Graphic signal of Williams Percent Range Strategy 
3) Strategy 1. In this strategy we use Exit Bollinger strategy with confirmation by williams percent range, which means buying when the Close price is below the Lower Band, and selling when the Close price is above the Upper Band. Close value is then confirmed by Williams percent range whether it is in the overbought or oversold area. We get overbought or oversold conditions if $\% \mathrm{R}$ line enters the -0 to -20 and -80 to -100 limits. 0 to -20 value will show overbought condition while value between -80 to -100 will show oversold condition. Figure 5 shows graphic signal of Strategy 1.

Close $\geqslant$ UpperBand and $\% \mathrm{R} \geqslant-20$, then Sell signal.

Close $\leqslant$ LowerBand and $\% \mathrm{R} \leqslant-80$, then Buy signal.

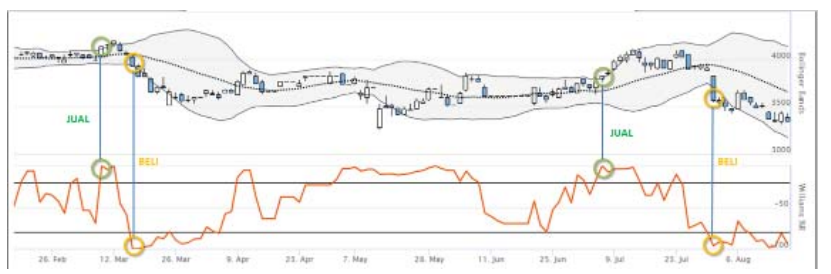

Fig. 5. Graphic Signal of Strategy 1

4) Strategy 2. This strategy follows the changing trends in Bollinger Bands by utilizing Middle Band and confirmation by Williams Percent Range. The price above the Middle Band indicates that the trend will go up and the price below indicates the trend will go down. By utilizing the trend of Bollinger Bands it can be obtained the possibility of price movements coupled with a confirmation from Williams Percent Range. Figure 6shows graphic signal of Strategy 2.

Low $\geqslant$ Middle Band and $\% \mathrm{R} \geqslant-20$, then Sell signal.

High $\leqslant$ Middle Band and $\% \mathrm{R} \leqslant-80$, then Buy signal.

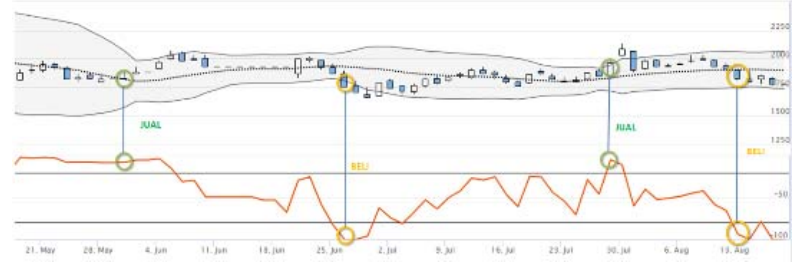

Fig. 6. Graphic Signal of Strategy 2

5) Strategy 3. This strategy is also utilizing trends from the Bollinger Band indicator, but by raising the confirmation parameter of Williams Percent Range by -50 . This strategy will be useful to increase the number of transactions so that it can cover the possibility of loss if there is a decrease in trends. Figure 7 shows graphic signal of Strategy 3.

Low $\geqslant$ Middle Band and $\% R \geqslant-50$, the Sell signal.

High $\leqslant$ Middle Band and $\% \mathrm{R} \leqslant-50$, then Buy signal.

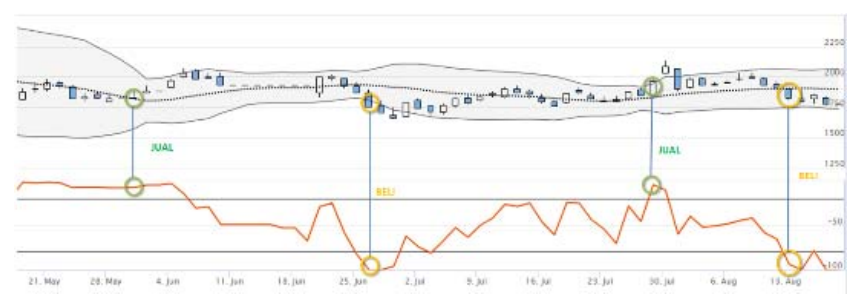

Fig. 7. Graphic Signal of Strategy 3

\section{Application Design}

We use UML to describe the application we are going to build. The use case diagram is shown in the Figure 1.

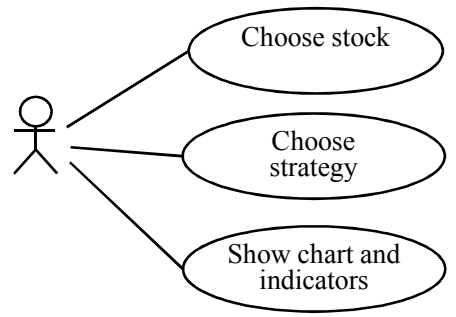

Fig. 8. Use Case Diagram

There will be three main use cases in this application based on Figure 8 as follows:

1) Choose stock: User can choose stock from six stock data provided.

2) Choose strategy: User can choose one from five strategy available

3) Show chart and indicator: The application will show chart and indicator following stock and strategy choosen by user.

Figure 9 show class diagram that describes the database of the system.

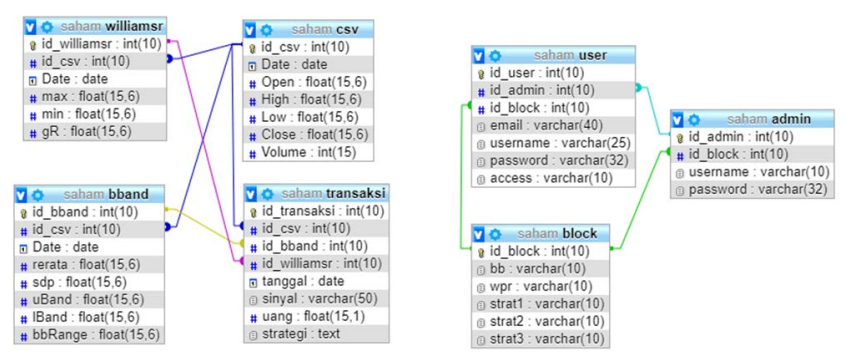

Fig. 9. Class Diagram

\section{RESUlt AND DisCUSSION}

In this section, we present implementation of the system, some presentations of our proposed system. At the end of this section, we discuss the performance of the proposed system.

\section{A. Implementation}

Implementation of this application is using the PHP as the programming language with MySQL as the database management system. We also use Sublime Text 3 as code editor tools. This application has six web pages, which are Home page, login page, admin page, LQ45 page, strategy page and about page. Home page contains the initial interface of an application. There are several functions on the home page, namely the logo chart button, admin tab, LQ45 tab, the about tab and the try now button. Login page is used for admin and user to log onto their account. User can also register if they haven't got a account. Admin page is used by the admin to control strategy that can be used by the user. LQ45 page shows the six LQ45 stock list provided by the application. About tab shows the information of the application developer. Strategy menu page shows five strategies that can be choosen by user. User will have to choose the company stock first. User then choose time period of the chart to be displayed. 
Figure 10 displays information and charts on INDY.JK stock with the indicator chart of Bollinger bands and Williams percent range. The chart can be displayed with time parameters, for example graphs in 1 month, 3 months, 6 months, and 1 year. User can scroll the chart horizontally and also print the chart using Print Chart menu.

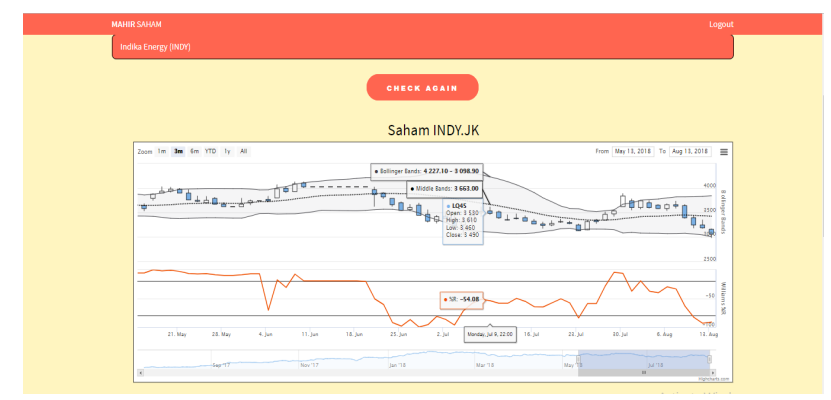

Fig. 10. Indika Energy Stock Chart

User can then choose the one from five strategy provided. Figure 11 shows signal resulted from Bollinger Band strategy from 1-year period.

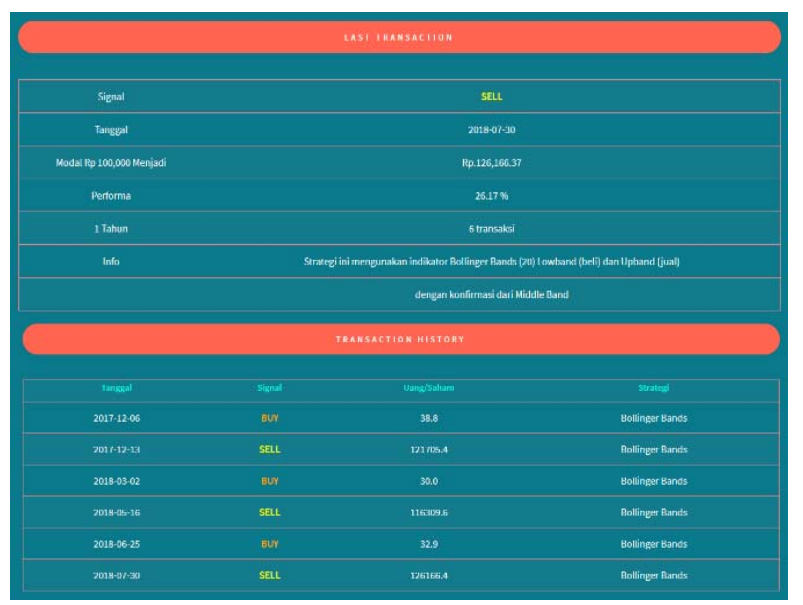

Fig. 11. Bollinger Bands Strategy Result Page

\section{B. Evaluation}

The results of the implementation of this strategy are the stages in which the strategy has been designed into the stock market. We then compare only three combined strategies performance to find the best strategy as shown in Table 1 .

The table show profit and loss obtained from implementing the combined strategy over a 1-year period from 28 August 2017 to 28 August 2018. While the result is mostly not favourable, but Strategy 1 is shown to be the best between 3 strategies presented with average profit $10,72 \%$. The most profitable strategy is when applied in ANTM stock with $80,2 \%$ profit.

The worst performance shown by strategy 3 with average of $8,03 \%$ loss, and the worst performance is when applied to PGAS stock with $40.88 \%$ loss.
TABle I. Strategy Performance

\begin{tabular}{|c|c|c|c|}
\hline \multirow{2}{*}{ Stock } & \multicolumn{3}{|c|}{ Performance } \\
\cline { 2 - 4 } & Strategy 1 & Strategy 2 & Strategy 3 \\
\hline INDY & $26.17 \%$ & $8.14 \%$ & $11.6 \%$ \\
\hline TLKM & $-13.21 \%$ & $-15.36 \%$ & $-14.13 \%$ \\
\hline ADRO & $10.57 \%$ & $17.26 \%$ & $22.89 \%$ \\
\hline ANTM & $80.2 \%$ & $12.42 \%$ & $-0.84 \%$ \\
\hline PGAS & $-27.78 \%$ & $-38.91 \%$ & $-40.88 \%$ \\
\hline WSKT & $-11.61 \%$ & $-20.42 \%$ & $-26.84 \%$ \\
\hline Average & $10.72 \%$ & $-6.15 \%$ & $-8.03 \%$ \\
\hline
\end{tabular}

\section{CONCLUSION}

Technical analysis as it is very suitable for predicting a stock price movement in the short term, medium term, or long term. Indicators combining is often used by investors to avoid false signals. Indicators combining is also used to complement between indicators. While this application is shown to be able to provide calculation of the Bollinger Bands and William Percent Range combination, the result is mostly not favourable.

Strategy 1 is shown to be the best between 3 strategies presented with average profit $10,72 \%$. The most profitable strategy was applied in ANTM stock with $80,2 \%$ profit.

The worst performance shown by strategy 3 with average of $8,03 \%$ loss, and the worst performance were applied to PGAS stock with $40.88 \%$ loss.

In order to get better result of application, more detail studies need to be conducted, using other combinations may increase the profit and minimize the loss. Using more stock data may also help to increase the accuracy of the application.

\section{REFERENCES}

[1] J. Anwar, Pasar Modal Sebagai Sarana Pembiyaan dan Investasi, PT. Alumni, Jakarta, 2005.

[2] R. Pardy, Institutional Reform Emergng Securities Markets, The World Bank, Washington DC-USA, 1992.

[3] F.T. Suharto, Mengungkap Rahasia Forex, PT. Elex Media Komputindo, Jakarta, 2011.

[4] P. Anoraga, P. Piji, Pengantar Pasar Modal, PT. Asdi Mahastya, Semarang, 2001.

[5] E. May, We Are Traders Not Gamblers, Vibby Printing, Jakarta, 2010.

[6] N.D. Ariansyah, Aplikasi Pendeteksi Sinyal Buy/Sell Saham Bursa Efek Indonesia (BEI) Melalui Indikator Bollinger Bands dan Relative Streght Index (RSI), Skripsi S-1, Universitas Diponegoro, Semarang, 2017.

[7] N. Sevani, M. Ariesta, Web-Based Decision Support Systems Application of Stock Recommendation Using Bayesian Methods Aplikasi Sistem Pendukung Keputusan Rekomedasi Stok Berbasis Web dengan Metode Bayesian, vol. 8, no. 1, pp. 1-10, 2014.

[8] D. Sulistiawan, Liliana., Analisis Teknikal Modern Pada Perdagangan Sekuritas, C.V Andi Offset, Yogyakarta ,2007.

[9] A. Habib, Kiat Jitu Peramalan Saham, C.V Andi Offset, Yogyakarta, 2008. 